\title{
Agricultural Soil Contamination by Heavy Metals in Slovakia
}

\author{
Ružena Králiková ${ }^{1, *}$, Miroslav Badida ${ }^{1}$, Miriam Andrejiová ${ }^{2}$, Tomáš Konkoly ${ }^{3}$ \\ 1 Department of Process and Environmental Engineering, Faculty of Mechanical Engineering, Technical University in Košice \\ 2 Department of Applied Mathematics and Informatics, Faculty of Mechanical Engineering, Technical University in Košice
}

\begin{abstract}
Worsened condition of living environment with a diverse degree of devastation in individual regions contributes negatively to a state of health of population and to a general ecosystem quality. Land presents a crucial natural resource and at the same time, an economic and eco-social potential of a country. Soil pollution is one of the major environmental problems. The presence of contaminants in soil environment has a considerable impact on land resources and can result in high values of exposure for people living in the vicinity of a contaminated site. Therefore, the evaluation of hazardous elements of soil pollution is one of the most important tools for overall assessment of the contaminated area. In addition to the properties and nature of land, also an actual attitude and approach of society to the problems of land protection influence significantly overall condition and development of land. For a remediation determination, additional information about utilisation and protection of land, a type and scope of agricultural land contamination is needed in connection to a spatial layout. It is possible to achieve a reduction of transport of pollutants into a food chain and crops by application of remediation methods for decontamination of specific pollutants from lands exposed to an anthropogenic pollution.

By this reason, hazardous contaminants, based on which a layout of agricultural land was formed according to overall degree of its contamination, were the object of the research in this paper. Within the agricultural land contamination, elements $\mathrm{As}, \mathrm{Cd}, \mathrm{Cr}, \mathrm{Cu}, \mathrm{Ni}, \mathrm{Pb}$ and $\mathrm{Zn}$ were assessed as hazardous ones taking percentage of contaminated soil into account in analysed samples from 63 districts, in order to obtain results about overall condition of the area contamination of agricultural land in Slovakia. The mutual dependence of individual monitored hazardous elements in sampling depth of $0-10 \mathrm{~cm}$ and $35-45 \mathrm{~cm}$ was determined. Within the research of the area contamination of agricultural land in the Slovak Republic, the multidimensional statistical methods and method of multiple comparisons were used. The analysis of monitoring of agricultural land contamination by heavy metals shows that regosols have the lowest content of almost all hazardous substances. On the contrary, agricultural land with higher degree of contamination by heavy metals occurs in various Slovak regions depending on a land type as well as a result of non-ecologic management in the past, e.g. due to application of fertilisers and pesticides and a nature of anthropogenic pollution, especially natural raw materials extraction, surrounding industry, transportation and so on.
\end{abstract}

Keywords: monitoring, contamination, agricultural soil, heavy metals, pollution.

\section{Introduction}

One of the most important current environmental problems that affects all the components of living environment is a global contamination of living environment. 
The contaminants are organic or inorganic compounds which naturally do not occur in living environment and we call them xenobiotics, or they occur in particular components of living environment in unnaturally high concentration, e.g. heavy metals. Due to the global contamination of living environment, the content of heavy metals increase also in a land ecosystem. In contrast to natural contents of heavy metals that are relatively inaccessible under suitable conditions, their anthropogenic contents are mostly in a mobile form, what presents a considerable risk for contamination of vegetal production or underground water $[2,14]$.

Soil, unlike other components of living environment, has a specific position in living environment, since here we come into contact with both organic and inorganic components, reversible and almost reversible parameters of land properties [20]. At present, a modern definition of land that recognize a broader extent of the land meaning is accepted in Slovakia, however, also higher responsibility for its protection that is stated in recommendation of the Council of Europe $\mathrm{R}(92) 8$ on land protection. According to its recommendation the land is an integral part of ecosystems of the earth and it is situated under surface and parent rock. The land is defined as an irreplaceable natural source with several natural functions that are worth of protection the highest degree in Act no. 34/2014 Coll. changing and amending Act No. 220/2004 Coll. on protection and utilization of agricultural land and, at the same time, it declares the significance of agricultural land as unrecoverable natural source and basic component of living environment.

By course of law, all the protection of agricultural land is based on six principles: (1) attention to agricultural land, its protection against (2) degradation, (3) erosion and (4) firming, (5) balances of soil organic material and (6) protection of agricultural land against dangerous substances. The attention of experts, as well as laymans is focused especially on dangerous substances, i.e. substances that are difficultly degradable in nature, have high persistency and often show toxic effects to living environment and human $[5,6]$. Among priority danger contaminants belong elements like arsenic, cadmium, cobalt, copper, nickel, lead, chromium and zinc. The contamination nature (anthropogenic or geoghenic) determines a remediation, further utilization and protection of land [8]. It ispossible to reach a reduction of pollutants transport into food chain and crop by an application of sanition methods for decontamination of specific pollutants from soils that were exposed to anthropogenic pollution [13]. Several experts deal with the soil contamination and its anthropogenic pollution refers to risks connected with the contamination of danger substances as a danger contaminant $[21,22]$. The risks connected with an application of the pesticides (fytopharmaceuticals), i.e. organic compounds intentionally used in agriculture, are given in study [7]. The influences of heavy metals on soil acidification and development of soil types are analysed in other knowen researche studies $[1,19]$. Therefore, the research object in this study includes priority risk contaminants, based on which the arrangement of agricultural land was carried out according to a total degree of their contamination by methods of multiple comparison. The solution also includes a spatial identification of soil contamination by monitored risk factors.

\section{Monitoring of Soil in Slovakia}

The monitoring of living environment in the Slovak Republic is provided by an integral monitoring system based on the operation of partial monitoring systems (air, water, geological factors, soil, biota, forests, radiation and other physical fields, foreign substances in foodstuffs and feed, population burden by environment factors), which able to provide data and information about condition and development of living environment and affecting influences [9]. Soil monitoring is understood as an integral part of living environment monitoring. Soil monitoring and evaluation of the condition and development of soil properties according to a specific threat (soil contamination, soil salinisation and sodification, organic matter decline, compaction and erosion of soil) is carried out in accordance with the European strategy of soil monitoring $[11,12]$. The most important parameters are permanently monitored within the soil monitoring, by EC recommendations for assessment of actual condition and development of soils [23]. In the context of the proposal of the European Commission, there is a systematic 
monitoring of soil variables in relation to their changes in quality, as well as soil protection and for provision of environmental control.

The monitoring network of soil in Slovakia is proposed on ecological principles and contains data on all major types and subtypes of soil, soil substrates in particular climatic areas in dependence on a contamination and utilization of soil. The complex monitoring of the soil in the Slovak Republic was carried out as a partial monitoring system. Soil was provided by the Soil Science and Conservation Research Institute in Bratislava. The partial monitoring system is of an area-wide nature, by which the development of agricultural soil, forest soil and soil above the forest border was monitored in entire Slovakia. The main goal of the soil monitoring is a systematic monitoring of the condition and development of the soil within the entire territory of the Slovak Republic with such spatial allocation of monitoring locations that describe the land fund of the Slovakia as a whole. On the basis of soil monitoring, data about its parameters and production as well as environmental functions of soil in space and time with the aim to determine and predict its developmental changes [24]. Presence of organic and inorganic contaminants is determined in soil samples by monitoring. At the monitoring, the attention is primarily focused on hazardous matters that are difficultly degradable, with high persistency and often have toxic impacts on living environment. Priority hazardous contaminants include the elements such as arsenic, cadmium, cobalt, copper, nickel, lead, chrome and zinc [3]. Agricultural land fund of Slovakia is characterised by long-term gradual decrease of agricultural land fund area, production arable land reduction into other soil categories, decrease of area of all categories of agricultural surfaces and considerable increase in an excess of fallow area of agricultural land (Report 2009-2013). Development of the land fund in the Slovak Republic within 1995 - 2010 is given in Tab. 1.

Total area in SR is approximately 4903531 ha. In 2013, agricultural land referred to share of $49 \%$ of total land area, forest land referred to share of $41.1 \%$ and nonagricultural and nonforrest land referred to share of $9.9 \%$. Slovakia is typical by high diversity of soil types, what is the consequence of differentiated geological, geographical and
Table 1: Development of the land fund in the Slovak Republic (SR) within $1995-2010$.

\begin{tabular}{|l|l|l|l|l|}
\hline & \multicolumn{5}{c}{ Part of total land area (\%) } \\
\multicolumn{1}{|c|}{ Land type } & $\mathbf{1 9 9 5}$ & $\mathbf{2 0 0 0}$ & $\mathbf{2 0 0 5}$ & $\mathbf{2 0 1 0}$ \\
\hline Agricultural land & 49,90 & 49,80 & 49,62 & 49,24 \\
\hline Forest land & 40,60 & 40,80 & 40,89 & 41,02 \\
\hline Water land & 1,90 & 1,90 & 1,91 & 1,93 \\
\hline Built-up land & 2,60 & 4,50 & 4,61 & 4,70 \\
\hline Other & 4,90 & 3,00 & 2,97 & 3,11 \\
\hline
\end{tabular}

climatic conditions. There are typical soils of lowlands and hilly area (chernozems, phaeozems, fluvisols, gleys), hilly areas (brown earth, regosols, pseudogleys), foothills (cambisols, rendzinas) up to typical mountain soils (podzols, leptosols, rankers). Andosoils are also rare within the territory of Slovakia. Saltmarshes and black alkali soils, as well as smonitzas, grey soils and organosols also occur rarely [12]. Hazardous substance loading in agricultural soils in SR is monitored directly within a partial monitoring system "Soil", as well as within its subsystem of area survey of soil contamination [17]. The monitoring system is provided by three subsystems: monitoring of soils in basic network, area survey of contamination of agricultural soils, monitoring of soils in selected key locations. The monitoring of soils in basic networks is carried out by Soil Science and Conservation Research Institute in Bratislava and Forest Research Institute in Zvolen and serves for permanent monitoring of the most important properties of soils in the entire territory of SR in regular, 5-year intervals. The area survey of contamination of agricultural soils is carried out by the Central Controlling and Testing Institute in Agriculture in Bratislava in connection to agrochemical testing of soils on selected plots of agricultural soils in cadastral territories of SR municipalities. The monitoring of soils in selected key locations serves for more detailed monitoring of development of soil properties and is carried out in the network of 21 monitoring locations in 1-year intervals.

The principle of monitoring of soils in SR consists in an ecological approach based on the network of monitoring locationswith pedological probes placed, representing all included soil types, subtypes, all manners of their utilization. In addition, they represent their occurrence in major 
climatic regions and in all territories of major types of contamination. The samples are taken from each monitoring area of agricultural soil from depth of $0-10 \mathrm{~cm}$ and $35-45 \mathrm{~cm}$. The basic monitoring network is created by 318 monitoring locations on agricultural soils and soils above upper forest border.

The 1st soil monitoring cycle in Slovakia was carried out from 1991-1995. There were the samples analyzed from totally 19,257 land tracts, what presents 782,905 ha, in this period. From the analyses point of view, totally 21,332 soil samples were analyzed and 107,314 analyses were made while monitoring 40 parameters - 10 inorganic, 30 organic ones [15]. The 2nd soil monitoring cycle was carried out from 1996 to 2000. During the cycle, 8,921 soil samples were analyzed, in which 105,351 analyses were made while 56 parameters were monitored 13 inorganic and 43 organic ones [9]. Within the 3rd soil monitoring cycle, which was carried out from 2001 to 2005, there were 7,605 soil samples analyzed in which 96,665 analyses were carried out, while 56 parameters -13 inorganic and 43 organic were monitored [10]. The 4th monitoring cycle was carried out from 2006. In order to fulfill the task, it was necessary to continue monitoring contents of contaminants in soils in selected cadastral territories. The samples were selected on the basis of results of previous monitoring cycles $[11,12]$. The results of the 2 nd monitoring cycle with sampling in 1997 showed that, compared to the 1st monitoring cycle, the condition of agricultural soil hygienically moderately improved [18]. A migration of hazardous components in a soil profile was proved and published in the Report on the state of the environment of the Slovak Republic in years 2009- 2010. [26].

The results of the 3rd monitoring cycle with sampling in 2002 showed that the content of the majority of hazardous components in selected agricultural soils of SR was below the limit, especially in the case of arsenic, chromium, copper, nickel and zinc. For cadmium and lead, above threshold values appeared in the soils situated in higher altitudes (podzols, andosoils). Chemical analyses of monitored soils were completed in 2010 (sampling year 2007) for selected monitored groups of agricultural soils: chernozems, brown earth, rendzinas, pseudogleys, kambisols, regosols, that create almost $65 \%$ of soil types in Slovakia.
Actual state of the analyzed soils was evaluated for the first time in the 4th monitoring cycle pursuant to Act No. 220/2004 Coll. and therefore it is not possible to make a comparison of a contamination with previous monitoring cycles. In 2013, the soil samples of new sampling cycle were taken so as to process and evaluate them gradually (published in the official report on the state of the environment of the Slovak Republic in years 2013) [26].

At analysis and evaluation of the contamination state of the agricultural land of the Slovakia by hazardous elements, basic statistical methods, multidimensional statistical methods and methods of multidimensional comparison were used. The utilization of multidimensional statistical methods within the monitoring of soil contamination we can find in many works $[4,16,25]$.

\section{Model of calculation}

\subsection{Contamination of Agricultural Land}

Within monitoring and analysis of contamination of agricultural soils, the contents of hazardous elements in soil were monitored by a decomposition by aqua regia for arsenic (As), cadmium (Cd), Cobalt $(\mathrm{Co})$, chromium $(\mathrm{Cr})$, copper $(\mathrm{Cu})$, nickel $(\mathrm{Ni})$, lead $(\mathrm{Pb})$ and zinc $(\mathrm{Zn})$. The measured minimum and maximum concentrations of particular hazardous elements in analyzed soil samples of the most spread types of agricultural land gained in the 4th sampling cycle (year of sampling 2007) are given in Tab. 2 - Tab. 5 (in mg.kg-1in aqua regia). Mutual dependence of monitored hazardous elements in the sampling depth of $0-10 \mathrm{~cm}$ a $35-45 \mathrm{~cm}$ is determined by correlation table given in Table 6 and Table 7.

Table 2: Concentrations of As, Cd, Co, Cr $\left(v \mathrm{mg} \cdot \mathrm{kg}^{-1}\right)$ in analyzed soil samples (sampled year 2007, sampling depth 0-10 cm).

\begin{tabular}{|c|c|c|c|c|c|c|c|}
\hline \multirow{2}{*}{\multicolumn{2}{|c|}{ Element }} & \multicolumn{6}{|c|}{ Soil types } \\
\hline & & 1 & ॥ & III & IV & V & VI \\
\hline As & $x p$ & 9,5 & 7,9 & 12,7 & 9,2 & 9,8 & 3,7 \\
\hline & Rv & $14,9-6,6$ & $18,8-2,0$ & $24,2-5,5$ & $15,5-3,1$ & $53,8-2,1$ & $4,3-3,0$ \\
\hline$C d$ & $x p$ & 0,18 & 0,21 & 0,41 & 0,24 & 0,30 & 0,10 \\
\hline & Rv & $0,38-0,03$ & $0,28-0,16$ & $0,78-0,1$ & $0,50-0,14$ & $1,3-0,1$ & $0,30-0,07$ \\
\hline$C_{0}$ & $x p$ & 8,8 & 11,7 & 10,0 & 10,0 & 10,2 & 2,0 \\
\hline & Rv & $10,9-6,6$ & $18,1-7,9$ & $22,0-3,8$ & $20,8-3,6$ & $28,3-4,9$ & $4,5-1,0$ \\
\hline $\mathrm{Cr}$ & $x p$ & 45,6 & 24,5 & 45,8 & 41,5 & 42,1 & 29,2 \\
\hline & Rv & $53,2-35,7$ & $34,0-17,2$ & $76,2-30,8$ & $74,1-10,8$ & $101,1-5,5$ & $50,1-18,5$ \\
\hline
\end{tabular}


Legend of the Tab. $2-$ Tab. $5 R_{v}=x_{\max }-x_{\min }, x p$ - average, I - chernozems, II - kambisols, III rendzinas, IV - brown earth, $\mathrm{V}$ - pseudogleys and luvisols, $\mathrm{VI}$ - regosols.

Table 3: Concentrations of Ni, Pb, Zn $\left(v \mathrm{mg} \cdot \mathrm{kg}^{-1}\right)$ in analyzed soil samples (sampled year 2007, sampling depth 0-10 cm).

\begin{tabular}{|c|c|c|c|c|c|c|c|}
\hline \multirow{2}{*}{\multicolumn{2}{|c|}{ Element }} & \multicolumn{6}{|c|}{ Soil types } \\
\hline & & I & $\|$ & III & IV & V & VI \\
\hline $\mathrm{Cu}$ & $x p$ & 21,6 & 23,2 & 22,6 & 22,9 & 18,0 & 22,6 \\
\hline & Rv & $37,2-15,0$ & $30,4-15,5$ & $37,5-11,1$ & $80,7-13,8$ & $44,7-9,5$ & $58,5-9,2$ \\
\hline $\mathrm{Ni}$ & $\mathrm{xp}$ & 27,8 & 9,2 & 31,7 & 32,6 & 25,3 & 15,0 \\
\hline & Rv & $31,5-22,9$ & $13,3-4,4$ & $72,7-13,0$ & $45,5-14,3$ & $100,0-0,2$ & $20,5-10,0$ \\
\hline $\mathrm{Pb}$ & $x p$ & 16,8 & 24,8 & 22,1 & 20,2 & 24,4 & 9,3 \\
\hline & Rv & $22,3-9,4$ & $45,2-13,6$ & $35,2-15,7$ & $47,4-5,5$ & $199,5-7,8$ & $17,9-5,0$ \\
\hline $\mathrm{Zn}$ & $x p$ & 66,5 & 80,2 & 76,5 & 68,8 & 67,3 & 45,8 \\
\hline & Rv & $112,0-50,4$ & $124,9-58,1$ & $133,9-48,5$ & $89,6-48,6$ & $198,7-42,0$ & $62,4-35,7$ \\
\hline
\end{tabular}

In agricultural land, in depth of 0 to $10 \mathrm{~cm}$, arsenic was cumulated in the concentrations ranging from $2-53.8 \mathrm{mg} \mathrm{kg}^{-1}$, with average of $8.8 \mathrm{mg} \cdot \mathrm{kg}^{-1}$. Arsenic showed predominantly stronger positive correlation to other monitored hazardous elements $(\mathrm{Cd}, \mathrm{Co}, \mathrm{Cr}$, $\mathrm{Ni}, \mathrm{Pb}, \mathrm{Zn}$ ) excluding $\mathrm{Cu}$, at which a weak negative correlation was detected. In the depth ranging from 35 to $45 \mathrm{~cm}$, a concentration of As ranging from 1.8 to $49.4 \mathrm{mg} \cdot \mathrm{kg}^{-1}$ with average of $8.9 \mathrm{mg} \mathrm{kg}^{-1}$. In this depth, As showed very strong positive correlation only for $\mathrm{Co}, \mathrm{Cr}, \mathrm{Pb}$ and $\mathrm{Zn}$. Very strong negative correlation was found between As and $\mathrm{Cu}$. The dependence between As content in the depth ranging from 0 $10 \mathrm{~cm}$ and in the depth ranging from $35-45 \mathrm{~cm}$ is not statistically significant. The average content of As for particular groups of analyzed soils shows that it is moderately increased in the depth ranging from $35-45 \mathrm{~cm}$, excluding the group of chernozem. The order of accumulation of arsenic for particular types of soil in the depth ranging from 0 to $10 \mathrm{~cm}$ and also in the depth ranging from 35 to $45 \mathrm{~cm}$, as it follows: regosols < kambisols < brown earth $<$ chernozem < pseudogleysand luvisols $<$ rendzinas.

In agricultural land, in depth to $10 \mathrm{~cm}, \mathrm{Cd}$ was cumulated in the concentrations ranging from 0.03 - $1.3 \mathrm{mg} \cdot \mathrm{kg}^{-1}$, with average of $0.24 \mathrm{mg} . \mathrm{kg}^{-1}$. Cadmium showed predominantly very strong positive correlation to other monitored hazardous elements excluding copper, at which a weak negative correlation was detected. In the depth ranging from 35 to $45 \mathrm{~cm}$, a concentration of
Table 4: Concentrations of As, Cd, Co, Cr ( $\left.\mathrm{vmg}^{\mathrm{kg}}{ }^{-1}\right)$ in analyzed soil samples (sampled year 2007, sampling depth $35-45 \mathrm{~cm}$ ).

\begin{tabular}{|c|c|c|c|c|c|c|c|}
\hline \multirow{2}{*}{\multicolumn{2}{|c|}{ Element }} & \multicolumn{6}{|c|}{ Soil types } \\
\hline & & 1 & $\|$ & ||I & IV & v & VI \\
\hline \multirow[t]{2}{*}{ As } & $x p$ & 9,1 & 8,6 & 12,7 & 9,1 & 9,8 & 3,9 \\
\hline & Rv & $14,4-4,5$ & $17,0-2,0$ & $20,7-5,6$ & $15,6-3,0$ & $49,4-1,8$ & $7,7-1,8$ \\
\hline \multirow[t]{2}{*}{$c d$} & $x p$ & 0,4 & 0,07 & 0,27 & 0,18 & 0,31 & 0,07 \\
\hline & Rv & $0,48-0,01$ & $0,13-0,02$ & $0,65-0,06$ & $0,48-0,05$ & $3,54-0,06$ & $0,12-0,01$ \\
\hline \multirow[t]{2}{*}{ Co } & $x p$ & 8,6 & 13,0 & 8,9 & 10,1 & 10,1 & 6,5 \\
\hline & Rv & $12,4-5,4$ & $15,8-10,4$ & $19,2-2,9$ & $21,5-4,6$ & $27,6-5,0$ & $14,2-1,8$ \\
\hline \multirow[t]{2}{*}{$\mathrm{Cr}$} & $x p$ & 46,0 & 28,0 & 46,8 & 45,9 & 47,3 & 29,2 \\
\hline & Rv & $62,5-32,5$ & $42,0-15,4$ & $77,7-26,5$ & $94,9-5,0$ & $81,3-6,9$ & $40,1-2,0$ \\
\hline
\end{tabular}

Table 5: Concentrations of Cu, Ni, Pb, Zn $\left(v \mathrm{mg} \cdot \mathrm{kg}^{-1}\right)$ in analyzed soil samples (sampled year 2007, sampling depth $35-45 \mathrm{~cm}$ ).

\begin{tabular}{|c|c|c|c|c|c|c|c|}
\hline \multirow{2}{*}{\multicolumn{2}{|c|}{ Element }} & \multicolumn{6}{|c|}{ Soil types } \\
\hline & & 1 & $\|$ & III & IV & V & VI \\
\hline $\mathrm{Cu}$ & xp & 20,0 & 19,0 & 19,5 & 20,1 & 18,8 & 22,8 \\
\hline & Rv & $39,1-12,1$ & $28,3-12,8$ & $36,7-6,9$ & $31,4-11,0$ & $41,2-9,8$ & $53,1-5,5$ \\
\hline $\mathrm{Ni}$ & $x p$ & 28,4 & 10,6 & 31,9 & 36,3 & 30,9 & 19,9 \\
\hline & Rv & $32,8-22,1$ & $17,6-4,0$ & $73,9-10,9$ & $51,2-16,9$ & $141,0-8,1$ & $55,9-7,2$ \\
\hline $\mathrm{Pb}$ & $x p$ & 13,5 & 15,2 & 18,2 & 16,6 & 17,8 & 8,5 \\
\hline & Rv & $19,5-7,9$ & $31,7-9,4$ & $34,1-7,4$ & $30,6-5,0$ & $74,8-7,1$ & $17,2-5,0$ \\
\hline $\mathrm{Zn}$ & xp & 63,7 & 67,4 & 67,2 & 68,0 & 64,4 & 59,0 \\
\hline & Rv & $129,2-41,0$ & $115,3-45,7$ & $135,0-21,2$ & $68,5-42,0$ & $111,0-42,4$ & $106,0-21,8$ \\
\hline
\end{tabular}

cadmium ranging from 0.01 to $3.54 \mathrm{mg} \cdot \mathrm{kg}^{-1}$ with average of $0.174 \mathrm{mg}^{\mathrm{kg}}{ }^{-1}$. In this depth, it showed very strong positive correlation only for arsenic, chromium, lead and zinc. The negative correlation was found between cadmium and copper, similarly like for arsenic. The dependence between cadmium content in the depth ranging from $0-10 \mathrm{~cm}$ and in the depth ranging from $35-45 \mathrm{~cm}$ is not statistically significant. The average content of cadmium for particular groups of analyzed soils shows that there is less cadmium in the depth ranging from 35 to $45 \mathrm{~cm}$ than in the depth ranging from 0 to $10 \mathrm{~cm}$. The order of accumulation of arsenic for particular types of soil in the depth ranging from 0 to $10 \mathrm{~cm}$ was as it follows: regosols<chernozems<kambisol $\mathrm{s}<$ brown earth $<$ pseudogleys a luvisols $<$ rendzinas and in the depth ranging from 35 to $45 \mathrm{~cm}$ it was as it follows: kambisols<regosols<chernozems $<$ brown earth<rendzinas < pseudogleys and luvisols. The dependence of arsenic content in the depth ranging from 0 to $10 \mathrm{~cm}$ and in the depth ranging from 35 to $45 \mathrm{~cm}$ is not statistically significant. 
Cobalt was cumulated in the concentrations ranging from $1-28.3 \mathrm{mg} \cdot \mathrm{kg}^{-1} \mathrm{in}$ the depth to $10 \mathrm{~cm}$, with average of $8.783 \mathrm{mg}^{\mathrm{kg}} \mathrm{kg}^{-1}$. In this depth, cobalt showed very strong positive correlation lead and zinc. It showed a weaker positive correlation also to arsenic and cadmium. Similarly, like for previous two cases, it showed a weak negative correlation for copper. In the depth ranging from 35 to 45 $\mathrm{cm}$, a concentration of cobalt ranging from 1.8 to 27.6 mg. $\mathrm{kg}^{-1}$ with average of $9.683 \mathrm{mg} \mathrm{kg}^{-1}$. In this depth, it showed very strong positive correlation with arsenic, cadmium, lead and nickel. Very strong negative correlation was found between cobalt and copper. Similarly, like for previous two cases, a mutual dependence between the concentration of cobalt in the depth ranging from $0-10 \mathrm{~cm}$ and in the depth from 35 to $45 \mathrm{~cm}$ was not confirmed. The average content of cobalt for particular groups of analyzed soils shows that there is increased content of cobalt in the depth ranging from 35 to $45 \mathrm{~cm}$ compared to the one in the depth ranging from 0 to $10 \mathrm{~cm}$, excluding the groups of agricultural soils of chernozem, rendzina. The order of cobalt accumulation for particular types of soil in the depth ranging from 0 to $10 \mathrm{~cm}$ was as it follows: regosols< chernozems $<$ rendzinas $<$ brown earth $<$ pseudogleys and luvisols<kambisolsand in the depth ranging from 35 to $45 \mathrm{~cm}$ it was as it follows: regosols<ch ernozems $<$ rendzinas $<$ brown earth $<$ pseudogleys and luvisols<kambisols. The mutual dependence between the concentration of cobalt in the depth of $0-10 \mathrm{~cm}$ and in the depth of $35-45 \mathrm{~cm}$ was not confirmed.

In agricultural land, in depth ranging from 0 to $10 \mathrm{~cm}$, chromium was cumulated in the concentrations

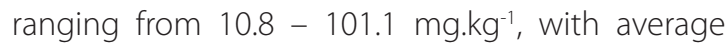
of $38.117 \mathrm{mg} \cdot \mathrm{kg}^{-1}$. Chromium showed positive correlation to all elements excluding copper. There was very strong positive correlation found to only two elements (As, Ni). In the depth ranging from 35 to $45 \mathrm{~cm}$, a concentration of chromium ranging from 2 to $94.9 \mathrm{mg} \cdot \mathrm{kg}^{-1}$ with average of $40.533 \mathrm{mg} \cdot \mathrm{kg}^{-1}$ was detected. In this depth, chromium showed positive correlation for almost all elements, except cobalt and copper. There was very strong correlation measured between chromium and nickel. The average content of chromium for all particular groups of soils shows that there is increased content of chromium in the depth ranging from $35-45 \mathrm{~cm}$ compared to the content in the depth ranging from $0-10 \mathrm{~cm}$. The order of chromium accumulation for particular types of soils in the depth ranging from 0 to $10 \mathrm{~cm}$ was as it follows: kambisols<regosols $<$ brown earth $<$ pseudogleys and luvisols $<$ chernozems $<$ ren dzinasand the one in the depth ranging from 35 $45 \mathrm{~cm}$ : kambisols<regosols<brown earth<chernoze ms $<$ rendzinas $<$ pseudogleys and luvisols.

Copper was cumulated in the concentrations ranging from 9.2 do $80.7 \mathrm{mg}_{\mathrm{kg}}{ }^{-1}$, with average of $21.817 \mathrm{mg}^{\mathrm{kg}} \mathrm{kg}^{-1}$ in agricultural land in the depth ranging from 0 to $10 \mathrm{~cm}$. This element showed a weak negative correlation in all cases except zinc, at which a weak, statistically not significant positive correlation was detected. In the depth ranging from 35 to $45 \mathrm{~cm}$, a concentration of copper ranging from 5.5 to $41.2 \mathrm{mg} \mathrm{kg}^{-1}$ with average of $20.033 \mathrm{mg} \cdot \mathrm{kg}^{-1}$ was detected. In this depth, copper showed negative correlation with all monitored hazardous elements. Statistically not significant negative correlation dependence was also confirmed between $\mathrm{Cu}-\mathrm{As}$, $\mathrm{Cu}-\mathrm{Co}, \mathrm{Cu}-\mathrm{Pb}$ and $\mathrm{Cu}-\mathrm{Zn}$.

In this case, a mutual dependence between concentrations of copper was not confirmed in the depth ranging from $0-10 \mathrm{~cm}$ nor in the depth ranging from $35-45 \mathrm{~cm}$. The average content of copper for particular groups of analyzed soils show that there is lower content of copper in the depth ranging from $35-45 \mathrm{~cm}$ compared to the content of the same in the depth ranging from $0-10 \mathrm{~cm}$, except the group of agricultural soils pseudogleys. The order of accumulation of copper for particular types of soils in the depth ranging from 0 to 10 $\mathrm{cm}$ was as it follows: pseudogleys and luvisols $<$ ch ernozems $<$ kambisols $<$ regosols $<$ rendzinas $<$ brown earthand in the depth ranging from 35 to $45 \mathrm{~cm}$ : pseudogleysand luvisols $<$ kambisols $<$ rendzinas $<$ brown earth $<$ regosols $<$ chernozems.

Nickel was cumulated in concentrations ranging from 0.2 to $100 \mathrm{mg}^{\mathrm{kg}}{ }^{-1}$ in the depth to $10 \mathrm{~cm}$ with the average of $23.600 \mathrm{mg} \mathrm{kg}^{-1}$. Similarly, like arsenic, nickel showed a positive correlation to other monitored hazardous elements $(\mathrm{Cd}, \mathrm{Co}, \mathrm{Cr}, \mathrm{Ni}, \mathrm{Pb}$, Zn), except for copper, at which a weak negative correlation was detected. There was far higher concentration of nickel detected in the depth ranging from 35 to $45 \mathrm{~cm}$ (from 4 to $141 \mathrm{mg}^{\mathrm{kg}}{ }^{-1}$, the average of $26.333 \mathrm{mg} \cdot \mathrm{kg}^{-1}$ ). Also in this case. Nickel showed a positive correlation with almost all elements, except cobalt and copper, at which a negative correlation was detected. The average 
Table 6: Correlation matrix of monitored hazardous elements (sampled year 2007, sampling depth 0-10 cm).

\begin{tabular}{llllll|l|l|l|l|}
\hline & As & Cd & Co & Cr & Cu & Ni & Pb & $\mathbf{Z n}$ \\
\hline As & 1 & & & & & & & \\
$\mathbf{C d}$ & $0,906^{*}$ & 1 & & & & & & \\
$\mathbf{C o}$ & 0,754 & 0,628 & 1 & & & & & \\
$\mathbf{C r}$ & 0,733 & 0,573 & 0,257 & 1 & & & & \\
$\mathbf{C u}$ & $-0,207$ & $-0,226$ & $-0,132$ & $-0,375$ & 1 & & & \\
$\mathbf{N i}$ & 0,679 & 0,568 & 0,243 & $0,945^{* *}$ & $-0,195$ & 1 & & \\
$\mathbf{P b}$ & 0,703 & 0,697 & $0,949^{* *}$ & 0,153 & $-0,281$ & 0,129 & 1 & \\
$\mathbf{Z n}$ & 0,757 & 0,665 & $0,952^{* *}$ & 0,159 & 0,086 & 0,148 & $0,900^{*}$ & 1 \\
\hline
\end{tabular}

${ }^{*} p$ - value $<0,05,{ }^{* *} p$-value $<0,01,{ }^{* * *} p$ - value $<0,001$

Table 7: Correlation matrix of monitored hazardous elements (sampled year 2007, sampling depth 35-45 cm).

\begin{tabular}{llllll|l|l|l|l|}
\hline & As & $\mathbf{C d}$ & $\mathbf{C o}$ & $\mathbf{C r}$ & $\mathbf{C u}$ & $\mathbf{N i}$ & $\mathbf{P b}$ & $\mathbf{Z n}$ \\
$\mathbf{A s}$ & 1 & & & & & & & \\
$\mathbf{C d}$ & 0,719 & 1 & & & & & & \\
$\mathbf{C o}$ & 0,410 & 0,110 & 1 & & & & & \\
$\mathbf{C r}$ & 0,702 & $0,825^{*}$ & $-0,050$ & 1 & & & & \\
$\mathbf{C u}$ & $-0,807$ & $-0,540$ & $-0,827^{*}$ & $-0,445$ & 1 & & & \\
$\mathbf{N i}$ & 0,482 & 0,728 & $-0,268$ & $0,917^{* *}$ & $-0,140$ & 1 & & \\
$\mathbf{P b}$ & $0,918^{* *}$ & 0,769 & 0,617 & 0,661 & $-0,885^{*}$ & 0,483 & 1 & \\
$\mathbf{Z n}$ & 0,222 & $-0,312$ & $0,847^{*}$ & $-0,430$ & $-0,552$ & $-0,601$ & 0,309 & 1 \\
\hline
\end{tabular}

${ }^{*} p$ - value $<0,05,{ }^{* *} p$ - value $<0,01,{ }^{* *} p$ - value $<0,001$

content of nickel for all groups of analyzed soils shows that there is increased content of nickel in the depth ranging from 35 to $45 \mathrm{~cm}$, compared to the content of the same in the depth ranging from 0 to $10 \mathrm{~cm}$. The order of nickel accumulation for particular types of soils in the depth ranging from $0-10 \mathrm{~cm}$ was as it follows: kambisols<regosols<pseudogleys and luv isols<chernozems<rendzinas<brown earth and the order of the same in the depth ranging from 35 to $45 \mathrm{~cm}$ was as it follows: kambisols<regosols<cherno zems $<$ pseudogleys and luvisols $<$ rendzinas $<$ brown earth.

Lead concentrations were cumulated from 5 to 199.5 mg. $\mathrm{kg}^{-1}$ in the depth ranging from $0-10 \mathrm{~cm}$, and the average amounted to $19.6 \mathrm{mg}^{\mathrm{kg}}{ }^{-1}$. The lower concentration of lead ranging from 5 to $74,8 \mathrm{mg} \mathrm{kg}^{-1}$ with the average of $14,967 \mathrm{mg}^{\mathrm{kg}}{ }^{-1}$ was detected in the depth ranging from 35 to $45 \mathrm{~cm}$. In both depths, lead showed a positive correlation to other monitored hazardous elements, except for copper, at which a negative correlation was detected. The average content of lead for groups of analyzed soils

show that there is considerably lower content of lead in the depth ranging from 35 to $45 \mathrm{~cm}$ compared to the one in the depth ranging from 0 to $10 \mathrm{~cm}$. The order of the lead accumulation for particular types of soils in the depth ranging from 0 to $10 \mathrm{~cm}$ was as it follows: regosols<chernozems<brown earth $<$ rendzinas $<$ pseudogleys a luvisols $<$ kambisols and in the depth ranging from 35 to $45 \mathrm{~cm}$ : regosols $<$ chernozems $<$ kambisols $<$ brown earth $<$ pseudogleys and luvisols $<$ rendzinas. There were high concentrations of zinc detected. In the depth to $10 \mathrm{~cm}$, zinc cumulated in concentrations ranging from 35.7 to $198.7 \mathrm{mg} . \mathrm{kg}^{-1}$, with the average of $67.516 \mathrm{mg} \mathrm{kg}^{-1}$. This element showed positive correlation in all cases, while very strong correlation dependence was confirmed between Zn-As, Zn-Co, $\mathrm{Zn}-\mathrm{Pb}$ and $\mathrm{Cu}-\mathrm{Cd}$. Somewhat lower concentration was detected in the sampling depth ranging from

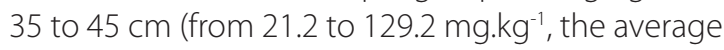
of $\left.64.95 \mathrm{mg} \cdot \mathrm{kg}^{-1}\right)$. In this case, a positive correlation with almost all elements was detected, except copper, at which a strong negative correlation was detected.The average content of zinc for particular 
groups of analyzed soils show that there is lower content of zinc in the depth ranging from $35-45$ $\mathrm{cm}$ compared to the depth ranging from $0-10 \mathrm{~cm}$, except for the group of agricultural lands containing kambisolsand regosols. The order of accumulation of zinc in particular types of soils in the depths ranging from 0 to $10 \mathrm{~cm}$ and from 35 to $45 \mathrm{~cm}$ was as it follows: regosols<chernozems<pseudogleys and luvisols<brown earth $<$ rendzinas $<$ kambisols and in the depth from 35 to $45 \mathrm{~cm}$ : rendzinas<reg osols $<$ chernozems $<$ brown earth $<$ pseudogleys and luvisols $<$ kambisols.

Total order of accumulation of particular hazardous elements in agricultural land in the sampling depth ranging from 0 to $10 \mathrm{~cm}$ was as it follows: $\mathrm{Zn}>\mathrm{Cr}>\mathrm{Ni}>\mathrm{Cu}>\mathrm{Pb}>\mathrm{As}>\mathrm{Co}>\mathrm{Cd}$. Similar order was in the sampling depth ranging from 35 to $45 \mathrm{~cm}$ : $\mathrm{Zn}>\mathrm{Cr}>\mathrm{Ni}>\mathrm{Cu}>\mathrm{Pb}>\mathrm{Co}>\mathrm{As}>\mathrm{Cd}$.

Particular types of agricultural soils were ordered by methods of multiple comparison according to total degree of contamination by hazardous elements. The order of total contamination was determined by three methods of multiple comparison - ordering method, scoring method and method of standardized variable. All monitored hazardous elements were considered as destimulating variables (a positive demonstration is their decrease). The resulting average order of contamination of selected types of agricultural land in the depth ranging from 0 to $10 \mathrm{~cm}$ and as well as in the depth of $35-45 \mathrm{~cm}$ is as it follows: regosols<kambisols $<$ chernozems $<$ pseudogleysa nd luvisols $<$ brown earth $<$ rendzinas.

\subsection{Contamination of Soil in Selected Districts in Slovakia}

We have characterized the level of contamination of soil by heavy metals in selected districts in Slovakia by six variables, which present the content of respective heavy metal in a soil sample (in $\mathrm{mg} / \mathrm{kg}$ ): $\mathrm{Cr}$ (chromium), Ni (nickel), Cd (cadmium), As (arsenic), $\mathrm{Hg}$ (mercury) a $\mathrm{Pb}$ (lead). Evaluating the area soil contamination, we took into account 63 districts, while measured values of particular variables present the average values of the first years of the $4^{\text {th }}$ monitoring cycle.We did not consider zinc $(\mathrm{Zn})$ and copper $(\mathrm{Cu})$ in our analysis, since these parameters were monitored in some districts only during the given period of time. The survey did not include the districts, in which soil sampling was not carried out during the monitored period of time (Bratislava (BA), Bánovce nad Bebravou (BN),
Bytča (BY), Košice (KE), Partizánske (PE), Revúca (RA), Tvrdošín (TS), Žarnovica (ZC)).

Based on chromium concentrations ascertained in particular districts, it results that Žilina (ZA) district is the most contaminated district. The order of five districts with the highest chromium content is as it follows: Žilina (ZA) > Myjava (MY) > ŽiarnadHronom $(Z H)>C ̌ a d c a(C A)>$ DunajskáStreda (DS).

Nickel highest value that exceeded the permitted limit value 3.8-times was measured in Myjava (MY) district. The order of five districts with nickel highest concentration is as it follows:Myjava (MY) $>$ NovéZámky (NZ)> Galanta (GA)>Púchov (PU)>TT.

Cadmium highest value that exceeded the limit value 3-times was measured for the given period of time in Čadca district.The order of districts with highest contamination of cadmium is as it follows: Čadca (CA) > Púchov (PU) > SL > BB > Žilina (ZA).

High above-threshold value of arsenic (185.90 mg. $\mathrm{kg}^{-1}$ ) was measured during the given period of time in Banská Bystrica district. This value exceeds the permitted limit value (5 mg/ $\mathrm{kg}$ ) 37.2-times. The order of five districts with highest arsenic concentration is as it follows: $\mathrm{BB}>\mathrm{GL}>\mathrm{ZH}>\mathrm{RV}>$ KS. Mercury highest value, amounting to almost 27fold of permitted limit $\left(0.3 \mathrm{mg} \cdot \mathrm{kg}^{-1}\right)$ was measured in Gelnica district during the monitored period of time. The order of districts with highest concentration of mercury is as it follows: $G L>S N>R V>Z H>L E$. During the monitored period, the value of lead exceeded the permitted value almost 5-times in Banská Štiavnica district. The order of the districts is as it follows: $\mathrm{BS}>\mathrm{BB}>\mathrm{ZH}>\mathrm{CA}>\mathrm{GL}$.

We obtained the analogical result by the method of analysis of major components. We replaced three input independent variables the values of which presented the average values of indicators in particular districts during the monitored period of time by three independent variables. The first component (explains $40.8 \%$ of data variability) is created predominantly by $\mathrm{Cd}$ and $\mathrm{Pb}$ parameters. The second component (explains 26.5\% of variability) consists of $\mathrm{Cr}, \mathrm{Ni}$ and As. The third component (14.4\% of variability) is created especially by $\mathrm{Pb}$ element. These new variables (the first three major components) cover together almost $80 \%$ of total variability in data.

Graphical representation of data of original variables in a coordinate system of one main component in relation to another main component 
is shown on Fig. 1. It results from the diagram obtained by the analysis of main components that Banská Štiavnica district (BS) and Žiar nad Hronom $(\mathrm{ZH})$ district contains a large share of $\mathrm{Pb}$ variable. Čadca (CA) district has a arge share in another element - Cd, Banská Bystrica (BB) in As variable and Myjava (MY) district in Ni variable. The diagram distributed the districts equally, on the basis of similarity of contamination degree, into several clusters. The large cluster is mainly created by districts with lower degree of soil contamination by heavy metals. The Gelnica (GL) district, Banská Bystrica (BB) district, Myjava (MY) district appear as strongly deviating districts.

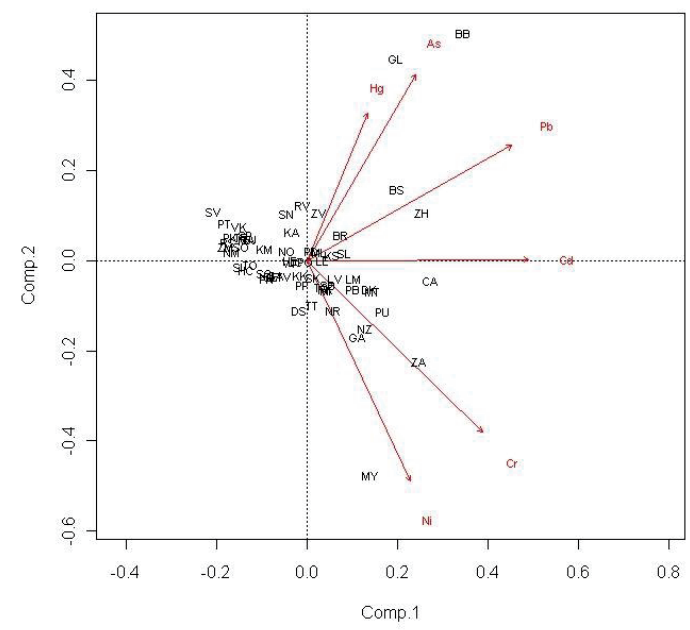

Fig. 1: Main components graph (biplot).

The analogical results we obtained by hierarchical agglomerative clustering by the method of average linkage. The district similarity dendrogram, which we have obtained as a result of the cluster analysis is shown on Fig. 2. The results of analysis referred to the fact that Gelnica (GL) district, Banská Bystrica (BB) district and Myjava (MY) district differ considerably from other districts. These districts are indisputably separated and create separate groups.

Another separate group is created by PT and SN districts. A larger cluster is created by CA, ZA, BS, $\mathrm{PU}$ and $\mathrm{ZH}$ districts. As in the previous districts, also these belong to the districts with higher values of parameters, which are typical for higher contamination below heavy metals. Additional three large clusters are created gradually by districts, in which the average values of monitored parameters below limit values were measured.
We arranged the monitored districts by the method of multiple comparison according to resulting degree of heavy metal contamination. We determined the level of a contamination by the method of standardized variable. All indicators were regarded as destimulating variables (a positive exhibition is their decrease). The resulting order of the first 10 districts with highest degree of contamination is as it follows: $\mathrm{GL}>\mathrm{BB}>\mathrm{PU}>\mathrm{ZH}>\mathrm{ZA}$ $>\mathrm{CA}>\mathrm{BS}>\mathrm{MY}>\mathrm{NZ}>\mathrm{SN}$ and 10 districts with the lowest degree: $M A>S P>S I P T R>V K>N M>R S>$ $\mathrm{PK}>\mathrm{ZM}>\mathrm{SV}$.

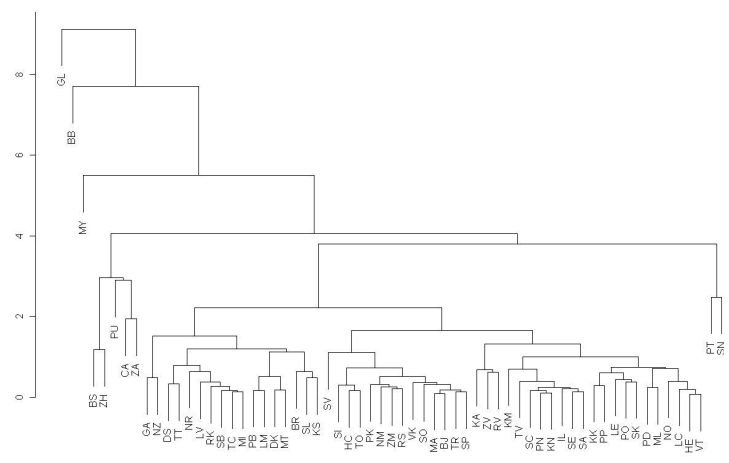

Fig. 2: Dendogram - Cluster analysis (Average linkage method).

\section{Conclusion}

The living environment contamination became one of the major social problems recently. The agricultural land presents the part of the land fund of the country which man consciously reshapes and utilizes so as to satisfy his/her needs. By this reason, as a natural component of living environment, it becomes the object of its interest, consideration and research. The land research focused on its identification and evaluation is the necessary prerequisite for reasonable utilization and protection of productional and nonproductional functions of land in SR, including modeling and creation of optimization programs of protection and efficient utilization of land as one of the basic components of living environment.

Hazardous substances belong among pollutants which are monitored in various components of living environment, including land. These substances belong to nondegradable contaminants, while their risks consist in ecotoxicity as well as in a cumulation in biotic and abiotic components of living environment. They participate in the circulation of substances what get them into the food chain and 
thus they may present a potential health risk for human. Within the contamination of agricultural land by hazardous elements, elements $\mathrm{As}, \mathrm{Cd}, \mathrm{Cr}$, $\mathrm{Cu}, \mathrm{Ni}, \mathrm{Pb}$ and $\mathrm{Zn}$ were evaluated.

Total order of accumulation of particular hazardous elements in agricultural land in the sampling depth ranging from 0 to $10 \mathrm{~cm}$ was as it follows: $\mathrm{Zn}>\mathrm{Cr}>\mathrm{Ni}>\mathrm{Cu}>\mathrm{Pb}>\mathrm{As}>\mathrm{Co}>\mathrm{Cd}$. The order was similar in the sampling depth ranging from 35 to $45 \mathrm{~cm}$ : $\mathrm{Zn}>\mathrm{Cr}>\mathrm{Ni}>\mathrm{Cu}>\mathrm{Pb}>\mathrm{Co}>\mathrm{As}>\mathrm{Cd}$. It follows from the results of agricultural land contamination monitoring analysis that regosols have the lowest content of almost all hazardous substances. It relates primarily to a low value of sorptive capacity of this soil type.On the contrary, higher concentration of hazardous substances are in the soil types with high to very high content of humus (e.g. rendzinas). The resultant average order of contamination of selected types of agricultural soil in the depth ranging from 0 to $10 \mathrm{~cm}$ and also in the depth ranging from 35 to $45 \mathrm{~cm}$ is as it follows: regosols $<$ kambisols< chernozems<pseudogleys and luvisols $<$ brown earth $<$ rendzinas.

Within the survey of area contamination of agricultural land in SR, multidimensional statistical methods were applied. The research was oriented to monitoring of land contamination by six most important heavy metals (chromium, cadmium, nickel, arsenic, mercury and lead) taking a percentage amount of contaminated soil in analyzed samples in 63 districts into account. The results of multidimensional statistical methods refer to the fact that Gelnica (GL), Banská Bystrica (BB) and Myjava (MY) districts seem to be deviated districts within the monitored period of time. These are the districts which had the highest measured values of monitored parameters. Districts Gelnica (GL), Banská Bystrica (BB), Púchov (PU), Žiar nad Hronom $(Z H)$, Žilina (ZA), Čadca (CA), Banská Štiavnica (BS), Myjava (MY), Nové Zámky (NZ) and Spišská Nová Ves (SN) belong, according to results of the methods applied, to the distristcs with highest degree of land contamination. On the other hand, Svidník $(\mathrm{SV})$, Zlaté Moravce (ZM), Poltár (PT), Pezinok (PK), Rimavská Sobota (RS), Nové Mesto nad Váhom (NM) districts belong to five districts with the lowest degree of land contamination by the occurrence of heavy metals.

It follows from the results of the research that the districts with higher degree of contamination of agricultural land by heavy metals are located in various regions of Slovakia and this degree of contamination depends for example also on soil type, extraction of mineral raw materials, surrounding industry, transport, application of fertilizers and pesticides. Total condition of land is considerably influenced by not only land properties and actual standpoint and society approach to the given problems, but, predominantly a treatment and careless conduct in the past.

\section{Acknowledgements}

The researchin this paper was supported by a grant "I Transfer of knowlledge from scientific researche activities into multimedial education process" KEGA - No 048 TUKE-4/2015 supported by Slovak Research and Development Agency (SRDA).

\section{References and Notes}

[1] Alloway, Brian J. (2012): Heavy Metals in Soils, Trace Metals and Metalloids in Soils and their Bioavailability, Environmental pollution (Book 22): 614

[2] Angelovičová L., Fazekašová D. (2014): Contamination of the Soil and Water Environment by Heavy Metals in the Former Mining Area of Rudňany (Slovakia), Soil \& Water Research, 9(1): 18-24.

[3] Castaldi, P., Melis, P., Silvetti, M. et al. (2009): Influence of pea and wheat growth on $\mathrm{Pb}, \mathrm{Cd}$, and $\mathrm{Zn}$ mobility and soil biological status in a polluted amended soil, Geoderma, 151 (34):241-248

[4] Facchinelli, As., Sacchi, E., Mallen, L. (2001): Multivariate statistical and GIS-based approach to identify heavy metal sources in soils. Environmental Pollution 114 (3): 313-324.

[5] Fazekašová, D., Barančíková, G., Torma, S., Ivanová, M., Manko, P. (2014): Chemical and environmental aspects of the components of the environment and landscape. 5th Central European Conference in Regional Science - CERS Slovakia.

[6] Friedlová M. (2010): The influence of heavy metals on soil biological and chemical properties. Soil and Water Research, (1): 21-27.

[7] Hronec, O., Tóth, J., Tomáš, J.(2002): Extraneous matter and their risks. HarlequinQuality, Slovakia.

[8] Huttmanova, Emilia; Adamisin, Peter; Hronec, Ondrej; et al.(2015): Possibilities of Soil Revitalization in Slovakia towards Sustainability, European Journal of Sustainable Development. 4(2): 121-128.

[9] Kobza, J., Barančíková, G., Došeková, A.Et Al. (2002): Monitoringof soils in Slovakia. The current state anddevelopmentof monitoringsoil propertiesasa basis fortheir protectionand further use: 1997-2001, Bratislava. 
[10] Kobza, J.,Barančíková, G., Čumová, L., Dodok, R. et al.( 2009): Monitoringof soils in Slovakia. The current state anddevelopmentof monitoringsoil propertiesasa basis fortheir protectionand further use: 2002-2006, Bratislava.

[11] Kobza, J., Barančikova, G., Dodok, R., Hrivňakova, K., Makovnikova, J., Mališ, J., Palka, B., Styk, J. \& Širaň M. (2010). Soil monitoring in Slovakia (in Slovak). Bratislava.

[12] Kobza, J., Barančikova, G., Dodok, R., Hrivňakova, K., Makovnikova, J., Mališ, J., Palka, B., Styk, J. \& Širaň M. (2011). Soil monitoring in Slovakia (in Slovak). Bratislava.

[13] Kobza, J., Gašová, K. (2014): Journal of Agricultural Science and Technology A,4(6): 504-513.

[14] Lee, C. S., Li, X., Shi, W., Cheung, S.C., Thornton, I. (2006): A multivariate analysis of water quality in Lake Naivasha. Science of the Total Environment 356 (1), 45-54.

[15] Linkeš, V. et al. (1997): Soil monitoring of Slovak Republic. Present state od Monitored Soil Properties (in Slovak). Bratislava.Soil Fertility Research Institute.

[16] Muhammad, S.,Shan,M.T.,Khan,S. (2011): Health risk assessment of heavy metals and their source apportionmentin drinking waterof Kohistan region, northern Pakistan. Microchemical Journal. 98. 334-343.

[17] Nováková, K. (2008): Surface soil contamination survey (Report). Central Control and Testing Institute in Agriculture, Bratislava.

[18] Nováková, K., Heroldová, T.(2009): Surface soil contamination survey (Report). Central Control andTesting Institute in Agriculture, Bratislava.

[19] Reddy, K.R., Cameselle, C. (2009): Electrochemical Remediation Technologies for Polluted Soils, Sediments and Groundwater, JohnWiley \& Sons, Inc., Hoboken, New Jersey. Report on the State of the Environmentof the Slovak Republicin 2009 - 2013.

[20] Skalski, T., Kędzior, R., Kolbe, D., Knutelski, S.(2015): Ground beetles as indicators of heavy metal pollution in forests, Sylwan. 159 (11):905-911.

[21] Senesil, G. S., Baldassarre, G., Senesi, N., \& Radina, B. (1999): Trace element inputs into soils by anthropogenic activities and implications for human health. Chemosphere, 39(2): 343-377.

[22] Takáč P., Kozáková L., Val'ková M., Zeleňák F. (2008): Heavy metals in the middle Spiš soils. Acta Montanistica Slovaca, 13: 82-86.

[23] Van-Camp, L., Bujarrabal, B., Gentile, A.R., Jones,R.J.A., Montanarella, L., Olazabal, C., Selvaradjou, S.K. (2004): Reports of the Technical Working Groups Established under the Thematic Strategy for Soil Protection. Office for Official Publications of the EuropeanCommunities EUR 21319 EN/5, Luxembourg.

[24] Vilcek, J.; Hronec, O.; Tomas, J.(2012): Risk Elements in Soils of Burdened Areas of Eastern Slovakia Polish Journal of Environmental Studies .21(5):1429-1436.

[25] Wong, S. C., Li, X. D., Zhang, G., Qi, S. H., Min, Y. S.(2002): Heavy metals in agricultural soils of the Pearl River Delta, South China. Environmental Pollution 119(1):33-44.

[26] The Rreports on the state of the environment of the Slovak Republic (2006-2013)

\section{Biographical notes}

Miroslav Badida, Dr.h.c. prof. Ing. PhD., he is a graduate of Mechanical Faculty of Technical University of Košice. His scientific and research work focuses on the field of environmental engineering. An accent is put on the issue of environmental management systems, ecologization of products and their production and life cycle analysis of products. Lately his attention is paid on research in the field of physical factors of working and living environment.

Ružena Králiková, doc. Ing. PhD., received M.S. degree in mechanical engineering form Technical University of Košice, Slovakia in 1980 and PhD. degree in 1996. She is an associated profesor of the Department of Environmental Sciences at the Faculty of Mechanical Engineering at the Technical University of Košice, Slovakia from 2001. Her researche interests include environmental monitoring, engineering and management, working environment, especially lighting and microclimate conditions of environment. She has autored of the monography, 6 textbooks and more than 100 journal and conference papers on this topics.

RNDr. Miriam Andrejiová, PhD., graduated in 1997 at Faculty of Science at Pavol Jozef Šafárik University in Košice in field of mathematics and physics. She obtained her postgraduate degrees in "Theory of Physics Teaching" at Faculty of Science at University of Pavol Jozef Šafárik in Košice. Since 1998 she has worked as assistant and special assistant at Department of Applied Mathematics and Informatics at Faculty of Mechanical Engineering at Technical University in Košice. Ing. Tomáš Konkoly, graduate on Faculty of Civil Engineering at the Institute of Environmental Studies, Technical University of Košice, Slovakia. 